\title{
News and Comments
}

This summer brought several changes to the editorial offices of the History of Education Quarterly. Most importantly, B. Edward McClellan resigned as editor, effective July 1, because of his appointment as chair of the Department of Educational Leadership and Policy Studies at Indiana University at Bloomington. Upon approval of the Board of Directors, William J. Reese was appointed to complete Ed's remaining threeyear term. Everyone associated with the journal will miss working with Ed on a daily basis. We wish him well with his new administrative challenges, and we will try to uphold his standards of editorial excellence.

Helping the Quarterly to achieve that goal will depend upon the assistance of many individuals. Ronald D. Cohen, associate editor, has kindly agreed to assume full responsibility for book reviews and essay reviews. During the past year, Ron has helped the journal in countless ways, and we are extremely pleased to acknowledge our indebtedness publicly. We are also happy to announce the appointment of another associate editor, David Adams of Cleveland State University. David will help evaluate manuscripts along with the members of our fine editorial board. Ron and David will be essential to the daily workings of the HEQ.

Professional journals cannot exist without various forms of institutional support. Academic administrators at three different universities deserve our thanks. Dean Howard Mehlinger of Indiana University at Bloomington remains a generous patron of the $H E Q$. Thanks must also be extended to two special friends at Bloomington: Richard Pugh of the School of Education and Morton Lowengrub of the College of Arts and Sciences. Peggy G. Elliott, chancellor of Indiana University-Northwest, has similarly been kind to our journal. At Cleveland State University, Professor J. Harrison Means and Dean John Harris III have enthusiastically supported David Adams's appointment. Dean Harris, formerly department chair at IU, was an enthusiastic supporter of the $H E Q$ when it first moved to Bloomington. His steadfast support is deeply appreciated.

During the past year we have benefited from an exceptional editorial board. Board members labor many hours evaluating manuscripts for publication and deserve many thanks. We cannot thank them enough for their friendship and generosity. 


\title{
CALL FOR PAPERS
}

\author{
Special Issue \\ The History of Literacy
}

In 1990 the History of Education Quarterly is planning to publish a special issue on the history of literacy. The purpose of this issue will be to advance scholarship on the study of literacy in its historical context. The United Nations has declared 1990 as the International Literacy Year.

We seek manuscripts that address broad issues in the field of literacy studies. We would like to receive manuscripts that examine the history of literacy in various national, regional, and world settings. Please submit manuscripts by September 1, 1989, to the Editor, History of Education Quarterly, School of Education, Room 203, Indiana University at Bloomington, Bloomington, Indiana 47405.

Please note: manuscripts should be prepared according to Style A of The Chicago Manual of Style (13th ed.), double spaced, and submitted in duplicate. Notes should be double spaced and placed at the end of the article. 